\title{
REBUILDING INDIA'S EXTERNAL TRADE: A SEARCH FOR OPPORTUNITIES IN MYANMAR
}

\author{
Lalrinchhani $^{1}$, C. Lalengkima ${ }^{2}$ \\ ${ }^{1}$ Asst Professor, Department of Political Science, Govt, J Buana College Lunglei \\ ${ }^{2}$ Asst Professor, Department of Political Science, St Xavier's College, Lengpui, Aizawl
}

Note: The paper is presented in National Conference in India Trade in Services in India and Exclusive Growth Paradigm at India Institute on Foreign Trade on 22-23. Aug 2013

Article DOI: https://doi.org/10.36713/epra8599

DOI No: 10.36713/epra8599

\section{INTRODUCTION}

Myanmar is a resource-rich country. It is endowed with precious mineral resources. Previously, Myanmar was called 'Rice bowl of the East' because of its fertile land and rich forest products. Not only in mineral resources, it is also rich in cultural aspects as well. Myanmar is also known as a 'home of many civilizations to the South East Asian nations'. However, it is one of the poorest countries in the world despite its richness in natural and mineral resources. It has been known as one of the most isolated countries due to its setback under the military rule. The economy was under strict governmental control and the poor economic policies virtually destroyed the whole economy. In other words, the economy of the country deteriorated due to poor management of resources. The people of the 'rice bowl of the east' were dying due to hunger and the morale of the people has been ruined. Many cases of human rights violation have been reported every year.

However, after reinstatement of democracy in Myanmar, many nations have shown interest on trade relation with Myanmar. It is hoped that the political freedom will change the trade environment in Myanmar. At this juncture, India is also taking advantages, and it is trying to enhance trade relationships with Myanmar in many fields, including the service sectors.

India is known to power the house of human resources related to service sector. It is a recognised super power in information technology. The presence of Indians in reputed and successful corporations have brought out the Indian superiority in information related technology. On the visit of
India's then Prime Minister, Manmohan Singh to Myanmar, an important agreement - the twelve (12) Memorandums of Understandings (MoUs) was signed between the two countries. Almost all of them are confident in building measures through the service sectors.

This paper will particularly concentrate on India's endeavour in helping Myanmar on skill development and increasing the human workforce and how the education related services like research and establishment of institute would help the bilateral trade. India is working on Myanmar's human development which is a significant way of searching for an opportunity. It is also anticipated that human development undertaking would generate more employment for many young people. In a reciprocal, Myanmar might offer what India needs from their possessions.

\section{INDO-MYANMAR COOPERATION IN EARLY PHASE}

India's connection with Myanmar has been immense. Indians started settling down in Myanmar (formerly known as Burma) as early as 1852, before Myanmar was annexed by the British under colonial India. As of now, almost $2 \%$ of the population are ethnic Indians. Most of the migrant Indians have taken refuge here during the British colonial period. Many ethnic Indians are still residing in Myanmar. India also paid a very special attention to NonResident Indian and Persons of Indian Origin living in Myanmar. The government has also established 'India Community Welfare Fund (ICWF)' scheme for Indian workers in Myanmar. The objective of the 
scheme is to provide assistance to the Overseas Indians in deserving cases ${ }^{\mathrm{i}}$.

After independence from the British rule, the two countries had started to build friendly relationship and have signed the Treaty of Friendship in 1951, to enhance the bilateral relationship. However, Indo-Myanmar relation has become inconspicuous due to the military rule in Myanmar. In 1987, when the then Prime Minister of India, Rajiv Gandhi visited Myanmar; the two countries laid foundations for reinforcing the relationship between them. However, the suppressive military action to Pro-democracy movement holds back the bilateral relationship.

In 1992-93, India, which was under the Prime Ministership of Narasimha Rao, revamped the foreign policy and started re-looking eastern Asian countries. India's 'Look East policy' has opened the door for renewing ties with eastern nations. The bilateral cooperation was initiated in many areas. India has been making cooperation with Association of South East Asian Nation (ASEAN) in a larger picture. In partnership with ASEAN, India got the status of 'Sectoral Dialogue Partnership' in 1992, later, 'Full Dialogue Partnership' in 1995 and 'Summit Partnership' in 2002. In the pursuit of cultivating close relationship, Myanmar is the door to reach the South Asian nations. Indo-Myanmar relationship is also taking a very good shape. To reinforce the relationship, a number of agreements have been made. Under the Prime Ministership of A.B. Vajpayee, India's relation with ASEAN nations is also very good. This policy has been continuing under the Prime Ministership of Manmohan Singh, which has enthusiastically taken important steps with Myanmar and has also increases the areas of cooperation.

Due to political restraint in Myanmar under the military junta; many nations had not shown interest on investing in Myanmar. However, some of the Asian countries including India and China continued investing and building trade relations with Myanmar. India and Myanmar have expansion of ties in diverse sectors like oil and gas exploration, information technology, hydro-power and construction of ports and buildings etc.

In the year 2008, a wind of change blew in Myanmar. The military junta took a bold step to reinstate democracy. Myanmar held constitutional referendum to give more power to the people, while new hopes and expectations were sowed among the people. The general election under the new democracy was held in 2010. The transformation of political situation in Myanmar has changed many important aspects. It has been changing the relationship with other nations too; many nations and organisations have welcomed the moves.
Since a long time back, Indo-Myanmar trade has been started and agricultural products have been dominating the bilateral trade. India's major exports into Myanmar are cotton yarn, auto parts, soya bean meal and pharmaceuticals, where chief imports from Myanmar are betel nut, dried ginger, green mung beans, black matpe, turmeric roots, resin and medicinal herbs. ${ }^{\text {ii }}$ As of now, according to Indian Embassy on Myanmar's website, India is the $4^{\text {th }}$ largest trade partner of Myanmar and $3^{\text {rd }}$ largest export destination and $5^{\text {th }}$ largest source of imports into Myanmar.

\section{TIGHTENING THE KNOT: INDIA'S PRIME MINISTER VISITED}

After 25 years gap of India's Prime Minister's visit to Myanmar, the then Prime Minister Manmohan Singh visited Myanmar on $27^{\text {th }}-29^{\text {th }}$ May, 2012. Prime Minister Singh has referred Myanmar as India's 'close friend and neighbour'. He has high expectation that his visit would take new initiatives and 'define a roadmap for the further development of cooperation in the years ahead'. India's External Affairs Minister, S.M Krishna, who accompanied the Prime Minister, said that India is ready to help Myanmar, "Myanmar is a developing country like India. They have come out of some problems internally and now they seem to be settling down and it is about time for them to devote time and launch a developmental agenda, I think people of Myanmar need India's assistance and India would be willing to assist them,

During the Prime Minister's visit to Myanmar, important agreements in 12 different areas were signed. The list of agreements and Memorandum of Understanding signed between India and Myanmar are:

-Memorandum of Understanding regarding US\$ 500 million Line of Credit.

- Air Services Agreement between India and Myanmar.

- Memorandum of Understanding on the IndiaMyanmar Border Area Development.

-Memorandum of Understanding on Establishment of Joint Trade and Investment Forum.

-Memorandum of Understanding on the Establishment of the Advance Centre for Agriculture Research and Education (ACARE).

-Memorandum of Understanding on

Establishment of Rice Bio Park at the Department of Agricultural Research in Nay Pyi Taw.

- Memorandum of Understanding towards setting up of Myanmar Institute of Information Technology. 
-Memorandum of Understanding on Cooperation between Dagon University and Calcutta University.

-Memorandum of Understanding on Cooperation between Myanmar Institute of Strategic and International Studies and Indian Council of World Affairs.

-Agreement on Cooperation between Myanmar Institute of Strategic and International Studies and Institute for Defence Studies and Analysis.

-Cultural Exchange Programme (2012-2015).

-Memorandum of Understanding on establishing of Border Haats across the border between Myanmar and India ${ }^{\text {iv }}$.

During the Prime Minister's visit, both countries agreed to emphasise on enhancing connectivity between the two countries as a means of promoting commercial, cultural, touristic and other exchanges between the people of the two countries. Both countries paid special attention on development cooperation, trade and investment, and recognised that power and energy sector is an area of great potential for cooperation. On initiation for people-topeople contacts, both countries agreed to launch trans-border bus service from Imphal connect to Mandalay. It is hoped that this connectivity would make significant progress on bilateral ties.

It was recognised that the Prime Minister's visit has generated a wide range of cooperation between the two countries. Both countries have realised the importance to pay more attention on border area development, transportation, connectivity, agriculture, trade and investment and promotion of friendly exchanges. They have recognized that peace and stability is necessary for development and welfare of the people. They also agreed to identify the need for special focus on the development and prosperity of the people in bordering areas. Both governments put a priority on border trade and readily agreed to identify and remove various impediments to bilateral trade. Indian companies were encouraged to make investments in construction of ports, highways, oil \& gas, plantation, manufacturing, hospitality etc ${ }^{\mathrm{v}}$. With the passage of time, India and Myanmar have also been changing the areas of cooperation. They are actively involved in both infrastructural and non-infrastructural sector The Prime Minister's visit has been dominated by human resources related cooperation.

\section{WHY SERVICE SECTOR IN INDO- MYANMAR TRADE?}

Trade in services is one of the most important aspects in international trade. The World Trade Organisation (WTO) has paid special attention to international trade in services. The WTO " General Agreement on Trade in Services (GATS)' is the first set of multilaterally negotiated and legally enforceable rules covering international trade in commercial services (i.e. excluding government services)" ${ }^{\text {vi }}$. India needs to pay particular attention to the trade in services. According to India's Economic Survey 2012-2013, India ranks $10^{\text {th }}$ in Service GDP in global scenario. In 2011, India's share of services exports increased from $0.6 \%$ in 1990 to $1.0 \%$ in 2000 and further to $3.3 \%$ in the world exports of services. Among the services, IT plays a crucial role. India proudly announces that, "India's IT and ITeS services with exponential growth are a unique exportled success story which has put India on the global map. While India has achieved a brand identity in this sector, other developing countries are trying to emulate India's example. Besides its impact on growth (both direct and indirect), it is also a provider of skilled employment both in India and abroad, generating direct employment for nearly 2.8 million persons and indirect employment of around 8.9 million in 2011-12,

Indian supremacy in information technology is recognised worldwide. On launching 'Akash 2' tablet, UN Secretary General, Ban Ki Moon praised India's advancement in information technology and said 'India is a super-power on the information superhighway". He also accepted that technological advancement could play a crucial role in development, "Information and communications technologies are engines of economic growth and development and can help transform people's lives." "viii India also expected that the advancement in information technology could transform the lives of the people of Myanmar.

India is not only superior in information related development technology, but also in the larger field of academia. Indian education is speedily growing and dynamic. Many important higher studies and research institutes have been growing after independence. According to the 2012 Global Innovation Index (GII), India ranked $64^{\text {th }}$. Even though India's position in GII is not high, the nonresident Indians and persons of Indian origin, who are working in different places, have revealed India's supremacy in academic, research and innovation. It was recorded that "as many as $12 \%$ scientists and $38 \%$ doctors in the US are Indians, and in NASA, $36 \%$ or almost 4 out of 10 scientists are Indians. If that's not a proof enough of Indian scientific and corporate prowess, digest this: $34 \%$ employees at Microsoft, $28 \%$ at IBM, $17 \%$ at Intel and 13\% at Xerox are Indians"ix. This clearly showed India's advancement and progress in educational research, and superiority in the fields of information technology.

Even though Myanmar is a dwelling place of precious minerals; it needs a technological and educational improvement to gain a sustainable and holistic development. However, the Myanmar 
education system under military rule has many set back, and their academic advancement is negligible. Denis Simon, Vice Provost for International Strategic Initiatives, Arizona State University, reflects Myanmar education,'The needs of higher education in Myanmar are extensive. The entire system requires nothing less than a complete renovation-from the physical infrastructure to the academic curriculum ${ }^{\mathrm{x}}$. The need for improvement of Myanmar education system has been wide-reaching. UN agencies and other international organisations have come out to help for better educational system in Myanmar.

The democracy has changed the trade scenario in Myanmar. Many nations are awakening to invest in Myanmar while many states have shown interest for resuming building relationship with Myanmar. The new environment has attracted large foreign investment. At this juncture, Myanmar needs to prepare well to handle the new development. IndoMyanmar cooperation on human resources development cooperation would sharpen the skills of Myanmar youth, and lead to advancement in agriculture technique, information technology and research and development. The human workforce would be increasing through the cooperation; Myanmar could deliver measurable values and accommodate more volume of trade, and strengthen ties with other nations.

\section{INDIA'S SERVICE SECTOR IN MYANMAR}

India chose to work together with Myanmar in different ways. It wanted to restore and enhance cooperation by lending a helping hand to Myanmar on soft skills development. Before the Prime Minister visited Myanmar, India was already aware of the high potentialities and facilitates Myanmar on educational related services. It expects that cooperation in service sector would bring greater speculation and prosperity under different schemes such as Indian Technical \& Economic Cooperation (ITEC), Technical Cooperation Scheme (TCS) of Colombo Plan and various scholarships offered by the Indian Council for Cultural Relations (ICCR) and special course for ASEAN diplomats. India has trained Myanmar in English language, information technology, computer application to agriculture, remote sensing, industries, urban development, parliamentary studies, mass communication, management, rural development, environment and renewable energy courses and other related areas ${ }^{\mathrm{xi}}$. The Prime Minister's visit has accelerated the cooperation. The slots allotted to Myanmar under ITEC have increased from 30 in 1999-2000 to 430 in the year 2012-13, and the TCS of Colombo plan from 45 in 1995-96 to 70 in the year 2012-2013.

In 2008, a premier institute was jointly established by India and Myanmar called 'India-
Myanmar Centre for Enhancement of IT Skills (IMCEITS)'. The IMCEITS was set up with an objective to produce IT manpower. Myanmar students have been trained in various courses at IMCEITS. Apart from the student, participants have included regular graduate/post-graduate students aspiring to join IT industry as well as government officials in various departments of Myanmar ${ }^{x i i}$. India helps Myanmar in setting up of specialised centre for entrepreneurship called 'Myanmar-India Entrepreneurship Development Centre (MIEDC)'. The MIEDC was jointly run by Entrepreneurship Development Institute of India (EDII) and The Yangon Institute of Economics. The EDII has been appointed the technical advisor for this project. The MIEDC is an outcome of Indian Initiative for ASEAN Integration (IAI) ${ }^{\text {xiii }}$. Besides that, MyanmarIndia Centre for English Language Training (MICELT) was opened in University of Foreign Languages, Malarsaung, Yangon and Pakkoku Industrial Training Centre.

As we have mentioned earlier, the Prime Minster's visit has expanded the cooperation in various service sector as well as human resources. During the Prime Minster's visit, both countries have emphasised on the human resources related cooperation. India has been targeting to upgrade building relation through service sector. It agreed to help setting up of the Advance Centre for Agriculture Research and Education (ACARE). Myanmar is known as a fertile land. However, due to poor management of agriculture, the production could not flourished in Myanmar. The advancement in agriculture, agricultural research and modern technology could help Myanmar increase in intensity of production. Besides, ACARE, both countries agreed to work in the establishment of Rice Bio Park at Nay Pyi Taw.

The ACARE is designed for 'Centre for Excellence' and is using cutting edge technology along with traditional knowledge and ecological conservation with financial and technical assistance from India. Rice Bio Park aimed to demonstrate available techniques of sustainable rice biomass utilisation. India is ready to help in the construction of a modern cyclone-proof rice silo within the Model Integrated Farm at Nay Pyi Taw. Besides the agreement, Myanmar requested for India's assistance in arranging training programmes/fellowships in the areas of dairy development, cattle breeding, vaccine technology and assistance in setting up a milk and milk product factory in Shan State.

Myanmar needs India's information technology supremacy. Even though Myanmar is advanced in science and mathematics ${ }^{\text {xiv }}$, its progress in the field of information technology is sluggish. India can help Myanmar to deliver the right solution. India agreed to help Myanmar in setting up of 
Myanmar Institute of Information Technology. The MIIT would be renowned Indian Institute Technology (IIT) patterned institution. It was expected that the MIIT would admit a first batch in September 2013. India's most reputed research institution in security and defence, run by the Ministry of Defence, the Institute for Defence Studies and Analysis (IDSA) agreed to help Myanmar Institute of Strategic and International Studies (MISIS). India's advancement and research on international affairs would be benefited by Myanmar. The Indian Council of World Affairs (ICWA) will cooperate with MISIS on international studies related research. Both IDSA and ICWA will help MISIS in research on international understanding, security and defence related research. India and Myanmar have thus been working on expanding in new venture and consolidating their ties.

The Memorandum of Understanding on cooperation between Dagon University and Calcutta University will open a new hope for hundreds of Myanmar students. The cooperation aims to cooperate in different areas like exchange of faculty, students and administrative managers, joint research, participation in seminars, academic meetings and short-term academic programmes and extra cocurricular activities like joint cultural programmes and study tours.

India's helping Myanmar on human resources development is an important instrument for searching opportunities in Myanmar. India invested to have stronger ties with Myanmar and is preparing to invest more in Myanmar. So, soft skill development likes educational cooperation, human resources development and information technologies are the important instruments. The cooperation would be an important instrument for helping each other, India will meet what Myanmar needs, in a reciprocal, and Myanmar may open up treasure to help India in another way.

Both countries have taken the cooperation seriously and they have taken action swiftly to implement the agreements. The task force for establishment of Rice Bio Park would be headed by renowned agriculture scientist, M.S. Swaminathan. The working party for establishment of Myanmar Institute of Information Technology (MIIT) is headed by $\mathrm{S}$. Ramadorai, advisor to Prime Minister. On November 2012, when S. Ramadorai visited Myanmar, the Vice-President of Myanmar, Sai Mauk Kham received the delegation. During the visit, both the countries discussed on designation land for construction of MITT in Mandalay, appointment of trainers and staff etc. Besides this agreement, India agrees to give out fellowship and 10 slots would be allocated every year for Myanmar researchers to work in Indian institutions.
India aided Myanmar to increase human capital and technological advancement. Due to geographical proximity, helping to fulfil the basic needs of Myanmar could not be a difficult task. In return, India could benefit from Myanmar's rich natural and mineral resources. Both countries could help each other to suffice their needs. So, India could be the best option to help Myanmar. India hopes that this service related trade would surely enhance the economy and could consolidate the country's GDP. It is hoped that this educational related service could bring much fortune for many Indian jobless youth. It could bring much employment though their knowledge and skills. India and Myanmar have thus been consolidating their ties through human resources development.

\section{WIN-WIN SITUATION: IMPACT OF COOPERATION IN SERVICE SECTOR}

Let us look how the India's investment in human resources related services would be beneficial for both countries. What will be the impact of cooperation in human resources development?

Configuration of the human capital: Capacity building is one of the important instruments for strengthening the bilateral relationship. The role of human capital in economic development is so laudable; it would help the country's development in innovation, productivity and growth. The IndoMyanmar relationship has been dominated by human development related service sector that has aimed at increasing the skill development and increasing the human capital. It is anticipated that, India's help of Myanmar would be useful in multilateral cooperation too. In the new dawn of Myanmar, the relationship between Myanmar and others countries have been increasing. Human capital formation would help in the ability to perform. The better the relationship, the better the trade, and the better investment in Myanmar could require preparation on human resources based development. So, Indian facilitation on Myanmar in human development would wake of attempts to prepare well for the future.

Exploring new venture for cooperation: The skill development and human development would help in making a better way for Indo-Myanmar bilateral ties. Both countries have been initiating to explore a new venture on relationship. India has been providing developmental aid to Myanmar. To have a better tie, both countries necessitate on discovering new areas, and new initiative for cooperation is required. India has been undertaking joint projects on diverse sectors in Myanmar. The possible bilateral trade volume has been increasing year by year. Indo-Myanmar trade could be accelerated by educating the people of Myanmar. In order to explore the full potential of 
Myanmar's prosperity, configuration of the human capital would play a crucial role. India is ready to extend a helping hand to support Myanmar's long term development priorities. It has been further developed to strengthen the bilateral trade relations. Service sector would be the best option for identifying new way of potential cooperation.

Increasing Cultural ties: India and Myanmar agreed on increasing social and cultural aspects. Both countries are keen to work for close bonding of the people and the programme of people to people contact could be achieved best through service sector cooperation. On reaching Myanmar, Prime Minister Singh has said that, "We have centuries of religious and civilizational ties with the people of Myanmar and I'm looking forward to my talks here" ${ }^{\text {xv }}$. Efforts on learning and research of both countries' history would help out to know more about the deep rooted relation, which will develop trust and confidence.

To strengthen the bilateral relationship and promoting people to people contact, India has been working on construction of roads and ports. The Indo-Myanmar friendship road and Koladan Multimodal Transit Transport Project, hope on enhancing the bilateral ties. However, the cooperation in service sector would put different people together and open a chance to interact intimately, and make the people closer.

Unemployment Solution: Indian tranquil faces acute unemployment problems. It has been estimated that the total number of unemployed or underemployed in India varies between 70 and 100 million people. Even though Indian economy has become flourishing, many educated persons are brought into being every year, the rate of unemployment has been escalating year by year. The cooperation between India and Myanmar on service sector will assist India in solving unemployment problems and vital element in Indian domestic economic policy too.

In every country, unemployment is one of the main problems. In India too, the causes of unemployment are overage, unqualified, vocational unfitness and physical disabilities. The qualified person too is facing unemployment due economic depression or sick industries etc. It is anticipated that the efforts on service sector would help the country's productivity and income levels would increase and there could be suitable remedial measures for reducing unemployment. It would surely sustain the dynamics of Indian supremacy in soft skill development. It will also provide an outlet to ease fighting the unemployment problems.

India searches for opportunities in a country rich like Myanmar. It found the chance to hand out on service related sector. It is hoped that these opportunities could help in increasing India's Service GDP, deepening and widening bilateral trade and have adequately developed positive outcome in all dimensions. India's cooperation with Myanmar on the service sector could be a win-win situation.' Myanmar could benefit India's service, so will India in retrospect.

India's search for opportunities in Myanmar are the foundation of India's venture in a larger cooperation with eastern Asian nations. It could facilitate India's effective cooperation in regional organisation like ASEAN and sub-regional cooperation like Mekong-Ganga Cooperation and BIMSTEC. Myanmar is known as a 'land bridge' between South Asia and South East Asian countries. ASEAN nations have great potential to be an important player in shaping India's future economic performance. The Indo-Myanmar bilateral ties in human resources would enhance India's undertaking in ASEAN countries. It is hoped that this provision in cooperation of service sector will accelerate to comply India's Look East Policy in many ways.

\section{CONCLUSION}

Myanmar is India's only South East Asian neighbour. Due to geographical proximity, India could maintain connection with Myanmar easily. Both countries have profound relationship in ethnic, cultural and religious fields. Both are former British colonies: Myanmar (Burma) is a part of colonial India till 1936. To consolidate the bilateral relations, India and Myanmar need to try out a new trend and have agreed to increase their areas like service related trade, better known as 'human resources development' in a larger field, could be the best instrument for building strong relationship. An energy-hungry country like India knows Myanmar's need for human resources development, which is a vital component for development programmes. It will help to provide access in more areas of cooperation. Both countries are collaborating earnestly to work together to gain a significant progress. Indian venture on service sector in Myanmar is not the first one. Previously, India helped Afghanistan on capacity building and developmental work successfully. It is hoped that India could also do a creditable job in Myanmar.

Friendship needs mutual action. India's Prime Minister's visit to Myanmar has urged both countries to build a stronger relationship. Many agreements have been already signed in paper. However, both countries need to work hard to implement those treaties and agreements. India has asked Myanmar to "upgrade cooperation to a comprehensive energy partnership, which would include sharing of Indian expertise and capacity-building" and expected positive outcome. India wanted to consolidate its relationship with Myanmar due to its desire for stability in the north-east, direct economic 
opportunities, transit trade and rising to check of China's influence in Myanmar ${ }^{\mathrm{xvi}}$. Whatever factors that might arise; India has cleverly used 'soft power' to have better ties with Myanmar.

The Indo-Myanmar relation resembles an old age method of 'barter system,' where India has offered help in capacity building and information technology. In return, India could get some benefits like expanding trade, exploring mineral resources and energy from Myanmar. The opening of new fortune in Myanmar has attracted many nations and there is a strong competition among nations to grab the fortune. Myanmar does not need only financial capital, but needs to develop configuration of human capital. Other nations may possibly construct roads, build ports, and fund many projects in ways of grants and loans to Myanmar, in order to win this tough competition. However, India uses instruments of capacity building to win in this competition.

\section{END NOTES}

${ }^{i}$ Ministry of External Affairs, Government of India. http://www.indiaembassy.net.

${ }^{i i}$ Ministry of External Affairs, Government of India. http://www.indiaembassy.net

iii "Prime Minister Manmohan Singh meets Myanmar President in landmark visit”,

http://www.ndtv.com/article/india/prime-ministermanmohan-singh-meets-myanmar-president-in-landmarkvisit-216643

${ }^{i v}$ Ministry of External Affairs, Government of India. http://meaindia.nic.in/meaxpsite/declarestatement/2012/05/ 28js01.pdf

${ }^{v}$ Manmohan Singh (2012), Prime Minter Office, Government of India. "PM's address to the think-tanks, intellectuals and Business Community in Yangon", http://pmindia.nic.in/speech-details.php? nodeid $=1180$

${ }^{v i}$ World Trade Organisation (2010), Measuring Trade in Services,

http://www.wto.org/english/res_e/statis_e/services_training _module_e.pdf

${ }^{\text {vii }}$ Ministry of Finance (2013), Ministry of Finance, Government of India, Economic Survey 2012-2013.

viii " $U N$ chief Ban Ki-moon praises India as superpower in information technology as he unveils Aakash 2 tablet". India Today, 29 November, 2012.

http://indiatoday.intoday.in/story/un-secretary-generalban-ki-moon-india-aakash-2-tablet-

datawind/1/235241.html ix Akshaya Mukul (2008), "36\% of scientists at NASA are Indians: Govt survey”, The Time of India. 11 March 2008.

${ }^{x}$ Denis Simon (2013) "Needs in the Higher Education Sector, Investing in the Future: Rebuilding Higher Education in Myanmar", Report on the IIE Myanmar Initiative, April 2013, Institute of International Education

${ }^{x i}$ Ministry of External Affairs, Government of India. http://www.indiaembassy.net.mm/index.php?option=com_c ontent \&view $=$ article \&id $=54 \&$ Itemid $=65 \&$ lang $=e n$

${ }^{x i i}$ Ministry of External Affairs, Government of India. http://www.indiaembassy.net.mm/index.php?option=com_c ontent $\&$ view $=$ article $\& i d=17 \&$ Itemid $=54 \&$ lang $=$ en

${ }^{x i i i}$ Ministry of External Affairs, Government of India. http://www.indiaembassy.net.mm/index.php?option $=$ com_c ontent $\&$ view $=$ article \&id $=18 \&$ Itemid $=41$ \&lang $=$ en

xiv I personally experienced that Myanmarese are advance in Science and Mathematics. Some of our friends also keening to choose Mathematics than other subjects in College days.

xv "Manmohan arrives in Myanmar: First Indian PM to visit in 25 years" The Times of India, 27. May 2012.

${ }^{x v i}$ Gareth Price (2013), India's Policy towards Burma, Chatham House Asia, ASP 2013/02, June 2013 